Sains Malaysiana 49(1)(2020): 93-101

http://dx.doi.org/10.17576/jsm-2020-4901-11

\title{
Protective Effect of Cocoa Extract on Ethanol Induced Liver Injury in Sprague- dawley Rats
}

(Kesan Pelindung Ekstrak Koko untuk Kecederaan Hati Teraruh Etanol pada Tikus Sprague-dawley)

\author{
Rosmawati Mat Shair, Mohamad Yusof Maskat*, Mohamad Khan Ayob \& Rosmin Kasran
}

\section{ABSTRACT}

Cocoa is a rich source of dietary polyphenol, highly potential antioxidant against free radicals. This study was designed to identify the effect of cocoa polyphenol extract in protecting from ethanol-induced liver injury in rats. Fifty male Sprague-dawley rats were divided into five groups fed with or without ethanol (4 g/ $/ \mathrm{kg} / \mathrm{d})$, cocoa extract (300 mg/kg/d) and silymarin $(200 \mathrm{mg} / \mathrm{kg} / \mathrm{d})$ continuously for 3 weeks using an enteral feeding protocol. All treatments were given orally every day for three weeks and continuously supply food and water ad libitum. Results showed that cocoa extract

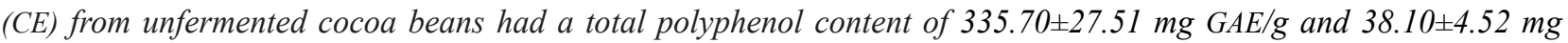

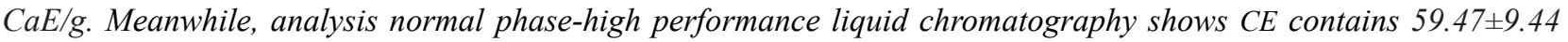
$\mathrm{mg} / \mathrm{g}$ and $14.69 \pm 1.63 \mathrm{mg} / \mathrm{g}$ of epicathechin and catechin, respectively, which is three fold higher compared to commercial cocoa powder. It also contains $59.69 \pm 2.15 \mathrm{mg} / \mathrm{g}$ theobromine which also three fold higher compared to caffeine $19.87 \pm 1.37 \mathrm{mg} / \mathrm{g}$. In vitro study showed cocoa extract contains high antioxidant activities by $91.9 \pm 1.00 \%$ against superoxide scavenging system $\left(\mathrm{O}_{2}^{-}\right)$and $97.7 \pm 0.15 \%$ against $\alpha$ - $\alpha$-diphenyl- $\beta$-picrylhydrazyl radical (DPPH) systems. In vivo study showed increasing level in both liver function enzymes, aspartase aminotransferase (AST) and alanine aminotransferase (ALT) in ethanol intoxication by $116.80 \pm 5.23 \mathrm{mmol} / \mathrm{L}$ and $56.37 \pm 2.71 \mathrm{mmol} / \mathrm{L}$, respectively. Ethanol intoxication was blocked by cocoa extract nearly $89.95 \pm 1.18 \mathrm{mmol} / \mathrm{L}$ and $46.75 \pm 0.74 \mathrm{mmol} / \mathrm{L}$, respectively, and it was comparable with SDT group for both enzymes AST and ALT by $112.19 \pm 6.02 \mathrm{mmol} / \mathrm{L}$ and $42.49 \pm 0.62 \mathrm{mmol} / \mathrm{L}$, respectively. Furthermore, ethanol groups showed significantly lower $(p<0.05)$ of glutathione level by $0.29 \pm 0.03 \mu \mathrm{mol} / \mathrm{g}$, however cocoa extract with antioxidant defense system either direct or indirectly protect liver injury by increasing glutathione level at $0.53 \pm 0.02 \mu \mathrm{mol} / \mathrm{g}$. As a result, cocoa extract shows its potential as antioxidant agents to protect ethanol-induced liver injury.

Keywords: Antioxidant activity; chronic ethanol; cocoa extract; glutathione; liver injury

\section{ABSTRAK}

Koko kaya dengan sumber polifenol diet bertindak sebagai antioksida dan berpotensi untuk menyingkirkan radikal bebas. Kajian ini dilakukan bagi mengenal pasti kesan ekstrak polifenol daripada koko untuk mencegah kerosakan hati tikus yang disebabkan oleh pengambilan etanol. Sebanyak lima puluh ekor tikus Sprague-dawley jantan, dibahagikan kepada lima kumpulan iaitu kumpulan kawalan, etanol (4 g/kg/d), ekstrak koko (300 mg/kg/d) dan silimarin (200 mg/ $\mathrm{kg} / \mathrm{d}$ ) yang mengandungi sepuluh ekor bagi setiap kumpulan. Setiap rawatan diberikan secara oral selama 3 minggu dan pengambilan makanan dan minuman adalah secara ad libitum. Analisis Folin-ciocalteau ekstrak koko (CE) telah menunjukkan bahawa jumlah kandungan polifenol ialah sebanyak 335.70 $27.51 \mathrm{mg} \mathrm{GAE} / \mathrm{g}$ dan $38.10 \pm 4.52 \mathrm{mg} \mathrm{CaE} / \mathrm{g}$. Manakala keputusan fasa normal kromatografi cecair berprestasi tinggi (NP-HPLC) pula menunjukkan ekstrak koko mengandungi kandungan epikatekin sebanyak $59.47 \pm 9.44 \mathrm{mg} / \mathrm{g}$ dan katekin sebanyak $14.69 \pm 1.63 \mathrm{mg} / \mathrm{g}$ iaitu tiga kali ganda lebih tinggi berbanding serbuk koko komersial. Ia juga mengandungi theobromina sebanyak 59.69 $2.15 \mathrm{mg} / \mathrm{g}$, iaitu tiga kali ganda kandungan lebih tinggi berbanding kafein iaitu $19.87 \pm 1.37 \mathrm{mg} / \mathrm{g}$. Kajian in vitro menunjukkan aktiviti antioksida ektrak koko adalah sangat tinggi iaitu sebanyak $91.9 \pm 1.00 \%$ terhadap radikal superoksida $\left(\mathrm{O}_{2}^{-}\right)$dan $97.7 \pm 0.15 \%$ terhadap radikal $\alpha$ - $\alpha$-difenil- $\beta$-pikrilhidrazil (DPPH). Manakala kajian in vivo menunjukkan berlaku peningkatan terhadap kedua-dua enzim fungsi hati iaitu enzim aspartase aminotransferase (AST) dan alanine

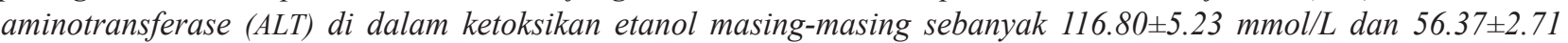
mmol/L. Ketoksikan etanol dapat dicegah dengan kahadiran ekstrak koko dengan kandungan enzim masing-masing adalah sebanyak $89.95 \pm 1.18 \mathrm{mmol} / \mathrm{L}$ dan $46.75 \pm 0.74 \mathrm{mmol} / \mathrm{L}$, selari dengan kumpulan silimarin bagi kedua-dua enzim AST dan ALT iaitu masing-masing $112.19 \pm 6.02 \mathrm{mmol} / \mathrm{L}$ dan $42.49 \pm 0.62 \mathrm{mmol} / \mathrm{L}$. Selanjutnya, kumpulan etanol menunjukkan penurunan yang signifikan $(P<0.05)$ kandungan glutation sejenis antioksida pertahanan badan semula jadi sebanyak $0.29 \pm 0.03 \mu \mathrm{mol} / \mathrm{g}$, walau bagaimanapun, kehadiran ekstrak koko yang bertindak samada secara langsung atau tidak langsung melindungi kerosakan hati telah meningkatkan kandungan glutation sebanyak $0.53 \pm 0.02$ $\mu \mathrm{mol} / \mathrm{g}$. Kesimpulannya, ekstrak koko telah menunjukkan bahawa ia sangat berpotensi sebagai agen antioksida dalam melindungi kerosakan hati yang disebabkan oleh pengambilan etanol.

Kata kunci: Aktiviti antioksida; ekstrak koko; etanol kronik; glutation; kerosakan hati 


\section{INTRODUCTION}

Increase of functional foods or nutraceutical products in the global market to prevent chronic diseases has become one of the major research fields lately. Cocoa is well known for its high flavonoid content, mainly catechin and epicatechin which has been proven as a potent antioxidant that react as a highly effective chemo preventive agent against chronic diseases including cancer, heart disease, diabetes, neurodegenerative disease and ageing (Kerimi \& Williamson 2015; Martin et al. 2016, 2013; Ramos 2008). In this sense, flavonoid compounds may be involved either directly or indirectly to scavenge or detoxify free radicals to prevent chronic diseases and increase human health. Indeed, direct antioxidant effects of flavonoids seemed to be partly based on their structural characteristics via hydrogen donating (radical scavenging) properties and their metal chelating antioxidant properties (Lambert \& Elias 2010; Nakagawa et al. 2004; Shahidi \& Ambigaipalan 2015). More importantly, flavonoids can avert free radicalinduced damage indirectly by modulating several enzymes related to oxidative stress, modifying the metabolism such as conjugating enzymes (glucuronidation, sulfation, acetylation, methylation and conjugation) as well as through regulation of certain transcription factors (Martin et al. 2016).

Beneficial actions of phytochemicals in cocoa and chocolate have been recognized by their biologically active compound or synergistic effects with other compounds such as methylxanthine, mainly theobromine and caffeine (Franco et al. 2013). Methylxanthine were reacts on adenosine receptors in the central nervous system, enhance erousal, mood and concentration levels (Nehlig 2010). In fact, the psychoactive properties of these methylxanthine was proven by Smit et al. (2004) which shown its psyhostimulant effect that give better daily life, i.e. more efficient thinking, exploring and focusing. Moreover, human and animal studies have indicated theobromine is able to suppress cough (Usmani et al. 2005) without the side effects by other antitussive drugs, such as codeine. It might be due to inhibitory effect on afferent nerve depolarization at peripheral and by blockade of adenosine receptors at molecular level and inhibition of phosphodiesterases or both (Coleman 1980).

Evidence from clinical studies by Khan et al. (2012) and Neufingerl et al. (2013) also shows theobromine from cocoa consumption significantly increase plasma HDL cholesterol levels and decreases LDL concentration, conferring to prevent cardiovascular and reduce risk of coronary heart disease. The benefits of caffeine in coffee was show reduction in the incidence of two of the most prevalent neurodegenerative disease: Parkinson's (costa et al. 2010) and Alzheimer's (Eskelinen et al. 2009; Maia 2002). Epidemiological studies also show intake of caffeine in dietary coffee during the middle age are less prone to suffer from neurological disease when they get older. With an agreement that the same methylxanthine occur in cocoa and fits it role by adenosine receptor blockade in the brain results in higher neuronal activity thereby enabling a longer life for these cells. The higher neuronal activity may be due to a regulation in the perfusion of the brain (Klaassen et al. 2013; Koppelstaetter et al. 2008; Pelligrino et al. 2010) and/or an increase in cerebral oxygen consumption (Haller et al. 2013). Another potential mechanism for neuroprotection may be an increased cerebrospinal fluid production (Han et al. 2009; Wostyn et al. 2011). However, the possible synergistic interactions between flavonoids and methylxanthines are still unclear and need further investigation.

Alcohol-induced liver disease remains one of the most common and deadly causes of chronic liver disease (Sussman et al.2002). Alcohol abuse has increased around the world, especially among young people who began to drink early (Hingson \& Howland 2002; Hingson et al. 2005). The hepatotoxicity of alcohol has often been attributed to its major metabolite acetaldehyde. In fact, acetaldehyde is capable of interacting with cellular constituents like proteins, glutathione or coenzyme A and may initiate hepatocellular damage by interacting with vital physiological functions (Szabo 2003). Elevation of enzymes alanine aminotransferase (ALT) and aspartase aminotransferase (AST) are the most sensitive indicator to hepatocellular injury (Strubelt et al. 1987) as well as nonenzymatic indicator namely glutathione thus directly reacts with free radicals (Valko et al. 2004). Previous study by McKim et al. (2002) has been shown that cocoa extract from Cocoapro cocoa (Mars, New Jersey) which composed more than $80 \%$ of flavanol epicatechin and epicatechinbased oligomeric procyanidins, protects against early alcohol-induced liver injury. Meanwhile, the purpose of this study was to identify the flavanolic content and antioxidant activity of Malaysia unfermented cocoa beans which would protect against ethanol induced liver injury in the rat enteral ethanol feeding model.

\section{Materials AND Methods}

\section{CHEMICALS AND STANDARD SOLUTIONS}

All solvents were of analytical grade and supplied by Sigma-Aldrich, Chemicals, Co. (St. Louis, USA) except for acetone, folin-ciocalteau reagent, methanol, acetic acid and dichloromethane supplied by Merck Chemicals (Darmstard, Germany) and hexane from J.T. Baker Chemicals (New Jersey, USA).

\section{PREPARATION OF PHENOLIC EXTRACT}

Cocoa fruits were supplied by Cocoa Research and Development Centre, Lembaga Koko Malaysia (LKM) at Hilir Perak. Cocoa fruits was breaking into two and cocoa beans was dried in an oven (Memmert, Germany) with blower at $60^{\circ} \mathrm{C}$ until the moisture content achieved of $4-6 \%$. Dried cocoa beans were defatted using a Soxhlet unit (Buchi, Switzerland) with hexane and cocoa extract which were extracted with $70 \%$ acetone. Cocoa extract were 
concentrated using rotary evaporator N-N-series (EYELA, USA) under partial vacuum at $70^{\circ} \mathrm{C}$ to remove hexane and aqueous extract were freeze-dried (LABCONCO, USA) and kept in $-40^{\circ} \mathrm{C}$ until used.

\section{DETERMINATION OF TOTAL PHENOLIC CONTENT USING FOLIN-CIOCALTEAU ASSAY}

Total polyphenol content in cocoa extract was determined according to the Folin-ciocalteau method (Adam 1928). Briefly, $0.1 \mathrm{~g}$ defatted cocoa seeds were dissolved in 10 $\mathrm{mL} \mathrm{70 \%} \mathrm{(v/v)} \mathrm{acetone} \mathrm{and} \mathrm{were} \mathrm{sonicated} \mathrm{(SONICATOR,}$ USA) for $30 \mathrm{~min}$. Samples were centrifuged (Universal $32 \AA$, Hettich Zentrifugen, Germany) at $5000 \mathrm{rpm}$ for 20 min. An amount of $100 \mu \mathrm{L}$ of the supernatant was added with $7.9 \mathrm{~mL}$ distilled water followed by $0.5 \mathrm{~mL}$ folinciocalteau reagent (previously diluted 10 -fold with distilled water) and allowed to stand at room temperature for 5-8 min. Then, $1.5 \mathrm{~mL}$ of $20 \%$ sodium carbonate $\left(\mathrm{Na}_{2} \mathrm{SO}_{3}\right)$ solution was added to the mixture. Mixtures were left at $20^{\circ} \mathrm{C}$ for $2 \mathrm{~h}$ and absorbance of each mixture was determined at $765 \mathrm{~nm}$ using UV-vis spectrophotometer (Shimadzu, Japan). A standard calibration curve was obtained from 0, 50, 100, 150, 250, 500, 750 and 1000 $\mathrm{mg} / \mathrm{L}$ gallic acid and catechin. Results were expressed as gallic acid equivalents (GAE) and catechin equivalents $(\mathrm{CaE})$ in milligrams per gram extract.

\section{QUANTIFICATION OF POLYPHENOL}

Identification and quantification of polyphenol compound was done according to the method of Hammerstone et al. (1999). A CLEAN-UP extraction column with C18 (500 $\mathrm{mg} / 3 \mathrm{~mL}$ ) for solid phase extraction (SPE) were purchased from UCT (Bristol, USA). The column was wetted with methanol and then conditioned with deionized water. Freeze-dried cocoa extract, approximately $100 \mathrm{mg}$ were suspended in $1 \mathrm{~mL}$ of water with the aid of sonication. A $250 \mu \mathrm{L}$ aliquot of the suspension was loaded onto the prewetted column, and the sugars were eluted with $20 \mathrm{~mL}$ of water. The phenolics were eluted from the column with $5 \mathrm{~mL}$ of a mixture of acetone, water and acetic acid in a ratio by column of 70:29.5:0.5, respectively. The columns were regenerated and the procedure repeated until the entire $100 \mathrm{mg}$ sample had been passed through the column. The elutes containing the sugars were discarded, whereas the phenolic-containing fractions were combined, concentrated by rotary evaporation and freeze-dried.

Chromatographic analyses were performed using high performance liquid chromatography (HPLC) Hewlett Packard 1100 series (Agilent Technologies, Waldbronn Germany) equipped with an autoinjector, quarternary HPLC pump, column heater, diode array detector and HP ChemStation for data collection and manipulation. Normalphase separations of the flavonoid were performed on a Supelco-Si column (Sigma, USA) $5 \mu$ silica column $(25 \times$ $4.6 \mathrm{~mm}$ ) at $37^{\circ} \mathrm{C}$. UV detection were recorded at $\lambda=280$ $\mathrm{nm}$. The ternary mobile phase consisted of (A) dichloromethane, (B) methanol and (C) acetic acid and water $(1: 1 \mathrm{v} / \mathrm{v})$. Results were analyzed and interpret. Quantification of theobromine, caffeine, epicatechin and catechin was carried out and used as a standard.

$$
\begin{aligned}
& \text { ANTIOXIDANT CAPACITY: SUPEROXIDE ANION }\left(\mathrm{O}_{2}^{-}\right) \\
& \text {RADICAL SCAVENGING ACTIVITY }
\end{aligned}
$$

Superoxide radical was generated using the Xanthine/ Xanthine Oxidase (X/XOD) Superoxide Scavenging assay by a modified method of Vimala et al. (2003). Nitro blue tetrazoleum (NBT) $(100 \mathrm{~mL}$ of $4.1 \mathrm{mM} / \mathrm{l})$ solution was prepared by adding $3.15 \mathrm{~g}$ tris hidro chloride (TrisHCl), 0.1 magnesium chloride $\left(\mathrm{MgCl}_{2}\right), 15.0 \mathrm{mg}$ bromo-4-chloro3-indolyl phosphate and $34.0 \mathrm{mg}$ 4-nitro blue tetrazolium chloride to $100 \mathrm{~mL}$ distilled water. Reaction mixture (100 $\mathrm{mL}$ ) was prepared by dissolving $0.53 \mathrm{~g} \mathrm{Na}_{2} \mathrm{CO}_{3}$ ( $\mathrm{pH} 10.2$ ), $4.0 \mathrm{mg}$ ethylenediaminetetraacetic acid (EDTA) and $2.0 \mathrm{mg}$ xanthine in $0.25 \mathrm{nMm}$ NBT solution and kept in refrigeration at $4^{\circ} \mathrm{C}$. Reaction mixture $(999 \mathrm{~mL})$ was transferred into micro cuvette and placed in a $25^{\circ} \mathrm{C}$ cell holder of a spectrophotometer. Superoxide was generated by adding $1 \times 10^{-3} \mathrm{U} / \mathrm{mL}$ of XOD and measured at $560 \mathrm{~nm}$ for $120 \mathrm{~s}$. Reaction mixture $(979 \mathrm{~mL})$ was transferred into micro cuvette and placed in a $25^{\circ} \mathrm{C}$ cell holder of a spectrophotometer. Superoxide dismutase (SOD) (1.16 U/ $\mathrm{mL})$ was added into the reaction mixture and mixed followed by XOD $\left(1 \times 10^{-3} \mathrm{U} / \mathrm{mL}\right)$ to generate oxyradicals and measured at $560 \mathrm{~nm}$ for $120 \mathrm{~s}$ at intervals of $10 \mathrm{~s}$. Acetone crude extracts of cocoa beans were dissolved in the reaction mixture at a concentration of $250 \mathrm{mg} / \mathrm{mL}$. The stock solution $(5 \mathrm{~mL})$ was added to $994 \mu \mathrm{l}$ of the reaction mixture and placed in a cell holder to auto zero. XOD $(1 \times$ $10^{-3} \mathrm{U} / \mathrm{mL}$ ) was then added and after thoroughly mixed, XOD and SOD curves were developed. Results of the scavenging effect were calculated based on the percentage of superoxide scavenged.

ANTIOXIDANT CAPACITY: FREE RADICAL SCAVENGING ACTIVITY ON A-A-DIPHENYL-B-PICRYLHYDRAZYL RADICAL

(DPPH)

The antioxidant activity of cocoa extracts was measured in terms of hydrogen donating or radical scavenging ability, using the 2,2-Diphenyl-1-picrylhydrazyl (DPPH) method of (Blois 1958) with slight modification. Crude acetone extracts of cocoa beans ( $4 \mathrm{~mL}$ of $0.5 \mathrm{mg} / \mathrm{mL}$ ) were added to $1 \mathrm{~mL}$ of DPPH ( $1 \mathrm{mM}$ in methanolic solution) in a $5 \mathrm{~mL}$ screw cap bottle. The solution was shaken and incubated at room temperature for $10 \mathrm{~min}$ and the decrease in absorbance at $520 \mathrm{~nm}$ was determined at the end of incubation period with a spectrophotometer. The remaining concentration of DPPH in reaction medium was calculated from a calibration curve obtained with DPPH at $520 \mathrm{~nm}$. The percentage of remaining DPPH $\left(\mathrm{DPPH}_{\mathrm{R}}\right)$ was calculated as following formula: \% $\mathrm{DPPH}_{\mathrm{R}}=\left[(\mathrm{DPPH})_{\mathrm{T}} /(\mathrm{DPPH})_{\mathrm{T}=0}\right] \times$ 100 , where $\mathrm{DPPH}_{\mathrm{T}}$ was the concentration of $\mathrm{DPPH}$ at the 
time of 60 min and $\mathrm{DPPH}_{\mathrm{T}=0}$ was the concentration of DPPH at time zero (initial concentration). Their scavenging effect was calculated based on the percentage of DPPH scavenged.

\section{IN VIVO ASSAYS: ANIMAL HANDLING}

The present study was approved by the Ethical Committee on the use of animals for the research, Department of Medicine and Health Science, Universiti Kebangsaan Malaysia (Selangor, Malaysia) with ethic approval no. FST/2016/MOHD KHAN/18-MAY/761-MAY-2016-AUG.-2018. Fifty male Sprague-dawley rats (160-180g) were purchased from Institute Medical Research (Kuala Lumpur, Malaysia) and acclimatized for 7 days. During this period, food and tap water were supplied ad libitum. The animals were housed in plastic cages with stainless steel covers and kept in rooms maintained at temperature $24-28^{\circ} \mathrm{C}$ and $30-70 \%$ relative humidity with a 12-h light/dark cycle.

\section{EXPERIMENTAL DETAILS}

Rats were randomly distributed into five groups $(\mathrm{N}=10$ for each group). Group I received only normal saline for a total period of three weeks and served as control (C). Animals of group II (CE) received $300 \mathrm{mg} / \mathrm{kg}$ cocoa extract for a total period of three weeks. For groups III (EtOH), rats received normal saline for the first week and normal saline plus $4 \mathrm{~g}$ ethanol for the following 2 weeks. Rats in groups IV (CE+EtOH) only received $300 \mathrm{mg} / \mathrm{kg}$ cocoa extract for the first week but for the following two weeks, rats were given both cocoa extract and ethanol. Group V received $200 \mathrm{mg} / \mathrm{kg}$ silymarin in water $(\mathrm{w} / \mathrm{v})$ for three weeks and also challenged with $4 \mathrm{~g}$ ethanol for the last two weeks. This ethanol dosage was based on preliminary studies which shown rats treated with $4 \mathrm{~g} / \mathrm{kg}$ ethanol produce liver injury after 3 days of experiments. However, rats treated with 5 and $10 \mathrm{~g} / \mathrm{kg}$ ethanol (referred to protocol by McKim et al. 2002) died after 3 days of experiments. All rats were given free access to water throughout the study period and treatment given via oral gavages for total of three weeks. The rats were weighed once a week.

\section{PREPARATION OF TISSUES AND BIOCHEMICAL ASSAYS}

After 3 weeks of study, the rats were anaesthetized with thiopental (50 mg/kg body weight, intraperitoneal) and sacrificed by exsanguinations. Five $\mathrm{mL}$ blood was collected from intracardiac cavity and placed into a vacutainer tube (BD Diagnostic, New Jersey, USA). The liver was quickly removed, weighed and freeze-dried with liquid nitrogen for further used.

Plasma enzymes For biochemical analysis, heparinized blood was centrifuged (Universal 32®, Hettich Zentrifugen, Germany) for $10 \mathrm{~min}$ at $1000 \mathrm{~g}$ at room temperature $\left(25^{\circ} \mathrm{C}\right)$. The supernatant was collected and plasma enzymes, AST (EC2.6.1.1) and ALT (EC 2.6.1.2) levels were measured using Chemistry Analyzer (Hitachi 902 Automatic Analyzer, Japan), as described in Roche (Roche Diagnostics $\mathrm{GmbH}$, Tutzing, Germany) kit leaflet.
Antioxidant assays Hepatic GSH content was measured after the reaction with 5, 5,-dithiobis-2-nitrobenzoic (DTNB) as substrate according to the method (Ellman 1959) with slight modification. This mixture was centrifuged (Bechman X22R, Indianapolis, USA) at 14,000 rpm for 30 min at $4{ }^{\circ} \mathrm{C}$. The volumes of supernatant were recorded. Three tubes were prepared and filled with $2.9 \mathrm{~mL}$ buffer solution pH8.0 and $0.1 \mathrm{~mL}$ supernatant. Twenty $\mu \mathrm{L} 10 \mathrm{mM}$ DTNB was also added into two tubes; one left as blank, and left for an hour in room temperature. The absorbance was read at $420 \mathrm{~nm}$ and the concentration of glutathione was calculated using following formula; Specific Activity of $\mathrm{GSH}=\mathrm{A} / \mathrm{E} \times \mathrm{V}_{\mathrm{s}} / \mathrm{V}_{\mathrm{i}} \times \mathrm{V}_{\mathrm{n}} / \mathrm{g} \times 1000$, where $\mathrm{A}$ is absorbance; $\mathrm{E}$ is molar absorbance coefficient $\left(13.6 \times 103 \mathrm{M} \mathrm{cm}^{-1}\right)$; $\mathrm{V}$. is supernatant volume $(\mathrm{mL}) ; \mathrm{V}_{\mathrm{i}}$ is volume of used supernatant $(\mathrm{mL}) ; \mathrm{V}_{\mathrm{n}}$ is homogenate volume $(\mathrm{mL})$ and $\mathrm{g}$ is tissue (liver) weight $(\mathrm{g})$. Results were expressed in $\mu \mathrm{mol} / \mathrm{g}$ liver.

\section{STATISTICAL ANALYSIS}

All data are presented as mean \pm S.E.M. (standard error mean). The data were analyzed using ANOVA test and Duncan New Multiple Range Test through Statistic Analysis System version 2.0 (SAS Institute, Cary, NC). Mean difference between groups of variables were tested with variance analysis (ANOVA). Two ended $p$ values less than 0.05 were considered as statistically significant.

\section{RESULTS AND Discussion}

\section{TOTAL POLYPHENOL CONTENT}

Cocoa beans are rich in important bioactive compounds which are flavonols (catechin and epicatechin) and metylxanthines (theobromine and caffeine) generally known to be beneficial for maintenance of health (Franco et al. 2013). Study by Othman et al. (2007) showed that Malaysian cocoa beans contain higher phenolic content compared to Sulawesi, Ghana and Ivory Coast cocoa beans. The high content of phenolic substances in cocoa beans not only resulted in the purple color in cocoa beans but also may contribute to bitter taste. Table 1 shows the results for phytochemical properties and in vitro antioxidant potential of cocoa extract from unfermented cocoa beans from Cocoa Research and Development Centre, Lembaga Koko Malaysia (LKM) at Hilir Perak. Our findings showed that the cocoa extract contained high level of total phenolic content (335.7 mg GAE/g, $38.10 \mathrm{mg} \mathrm{CaE} / \mathrm{g}$ ) surpassing green tea which has about $117.30 \mathrm{mg} \mathrm{GAE} / \mathrm{g}$ (Samman et al. 2001) and could be an important source of antioxidant. However, several factors may affect the levels of total phenolic content in cocoa beans such as location, growing conditions, harvesting period, cultivation, sampling and analytical procedures and thus, could also affect the antioxidant activity.

Antioxidant actions of phytochemicals have been recognized by their biologically active polyphenol 
compounds such as flavonoids and phenolic acids, which possess powerful antioxidant activities. In fact, these polyphenols act as oxidation terminators by scavenging free radicals to form stable ones (Rice-Evans \& Miller 1997). Here, our findings from NP-HPLC shows cocoa extract contained high epicatechin and catechin content by $59.47 \pm 9.44 \mathrm{mg} / \mathrm{g}$ and $14.69 \pm 1.63 \mathrm{mg} / \mathrm{g}$, respectively (Table 1). In comparison with commercially polyphenol rich cocoa powder, named CocoanOX only contain $19.36 \mathrm{mg} / \mathrm{g}$ epicatechin (Cienfuegos-Jovellanos et al. 2009) which is 3 -fold lower compared to cocoa extract. This high flavonoid content implies its functions as a potent antioxidant against free radicals, contributing to health maintenance through its protective properties. In addition, the existence of theobromine and caffeine has also been linked to promote health benefits and are remarkable through their physiological effect. Here, our findings show theobromine content from LKM unfermented cocoa beans which are $59.69 \pm 2.15 \mathrm{mg} / \mathrm{g}$ was 3 -fold higher compared to the caffeine which is $19.87 \pm 1.37 \mathrm{mg} / \mathrm{g}$ in the cocoa extract. Indeed, the higher theobromine content in cocoa is probably due to the N-methyltransferase-catalyzed metabolism of theobromine to caffeine in the four-step caffeine biosynthesis pathway (Ashihara et al. 2008). Considering the variation of methylxanthines in cocoa beans, the accumulation of these compounds occurs in the late development of the seeds as reported by Pereira-Caro et al. (2013). Psycoactive properties of methylxanthines have been revealed by their mechanisms mainly acting as adenosine receptor blockers in every cell (Orru et al. 2011).
As cocoa extract contains high phenolic content, our findings shows in vitro high antioxidant activities was 91.9 $\pm 1.00 \%$ against superoxide scavenging system $\left(\mathrm{O}_{2}^{-}\right)$and $97.70 \pm 0.15 \%$ against $\alpha$ - $\alpha$-diphenyl- $\beta$-picrylhydrazyl radical (DPPH) systems (Table 1). In this regard, several studies show this antioxidant capabilities of flavonoids compound having direct antioxidant action from the ability to scavenge free radicals, chelate redox-active metals and attenuate other process involving reactive oxygen species (ROS) (Fraga 2007; Hollman et al. 2011). Significant amounts of flavonoid monomers (catechin and epicatechin) in cocoa extract possess as highly potential antioxidant agent that may be applied in conjunction with medicines to promote health benefits.

\section{BODY WEIGHT}

In vivo study of the effect of cocoa extract on body weight of rats intoxicated with ethanol is shown in Table 2. The mean weight of rats in each group between days 0 and day 21 did not differ from each other $(P>0.05)$ in \% normality of body weight in all groups. The minimum body weight of rats was $110 \mathrm{~g}$ and the maximum is $250 \mathrm{~g}$. There was a pattern of increasing \% normality of body weight of rats given $300 \mathrm{mg} / \mathrm{kg}$ cocoa extract and $200 \mathrm{mg} / \mathrm{kg}$ silymarin drugs by $204.17 \pm 3.00 \%$ and $240.00 \pm 5.78 \%$, respectively. However, decreasing pattern of $\%$ normality of body weight of rats occurs but not significantly different $(P>0.05)$ in groups given $4 \mathrm{~g} / \mathrm{kg}$ ethanol and mixture of $300 \mathrm{mg} / \mathrm{kg}$ cocoa extract plus $4 \mathrm{~g} / \mathrm{kg}$ ethanol by $180.83 \pm 20.67 \%$ and $184.00 \pm 18.87 \%$, respectively.

TABLE 1. Phytochemical properties of cocoa extract and its in vitro antioxidant potential

\begin{tabular}{lc}
\hline \multicolumn{2}{c}{ Biochemical Analysis } \\
\hline Total polyphenol content (mg GAE /g) & $335.70 \pm 27.51$ \\
Total polyphenol content (mg CaE /g) & $38.10 \pm 4.52$ \\
Theobromine (mg/g) & $59.69 \pm 2.15$ \\
Caffeine (mg/g) & $19.87 \pm 1.37$ \\
Epicatechin (mg/g) & $59.47 \pm 9.44$ \\
Catechin (mg/g) & $14.69 \pm 1.63$ \\
Superoxide Scavenging (\%) & $91.9 \pm 1.00$ \\
DPPH Radical Scavenging (\%) & $97.7 \pm 0.15$ \\
\hline
\end{tabular}

Data are express as means \pm SEM $(n=3-4)$ gallic acid equivalents $(\mathrm{GAE})$ and catechin equivalents $(\mathrm{CaE})$

TABLE 2. Effect of cocoa extract on \% normality of body weights of rats intoxicated with ethanol

\begin{tabular}{lc}
\hline Groups & \% normality of body weights \\
\hline Control (distilled water) & $186.25 \pm 16.50 \mathrm{a}$ \\
$300 \mathrm{mg} / \mathrm{kg}$ cocoa extract & $204.17 \pm 3.00 \mathrm{a}$ \\
$4 \mathrm{~g} / \mathrm{kg}$ ethanol & $180.83 \pm 20.67 \mathrm{a}$ \\
$300 \mathrm{mg} / \mathrm{kg}$ cocoa extract $+4 \mathrm{~g} / \mathrm{kg}$ ethanol & $184.00 \pm 18.87 \mathrm{a}$ \\
$200 \mathrm{mg} / \mathrm{kg}$ silymarin $+4 \mathrm{~g} / \mathrm{kg}$ ethanol & $240.00 \pm 5.77 \mathrm{a}$ \\
\hline
\end{tabular}

Data are express as mean \pm SEM $(\mathrm{n}=10)$ for each group for 3 weeks. Mean values followed by same alphabet in the same column are not significantly different at $\mathrm{p}>0.05$ 


\section{PLASMA ENZYMES}

It has been shown that consumption of ethanol damages the cells and affects liver function, which may lead to alcoholic liver disease (ALD), characterized by liver failure (Lieber 1997; Nordman 1994). Metabolism of ethanol generated production of free radicals and plays a major role in ethanol-induced oxidative stress. Oxidative stress is an important mechanism of ethanol-induced liver injury and is associated with increased serum level of transaminase (Caballeria 2003). It is support by McKim et al. (2002) show serum ALT progressively increased in animal fed with alcohol. Similarly, our findings also show significantly increased $(\mathrm{P}<0.05)$ level of both enzymes AST and ALT in EtOH groups by $29 \%$ and $27 \%$, respectively (Table 3 ) compared to control groups. However, our findings also reported the protective properties of the cocoa extract, which was able to protect the hepatic function by preventing damages due to ethanol consumption. In fact, ALT is a cytoplasmic enzyme released into circulation in response to damage to the structural integrity of the liver cells (Sallie et al. 1991), and it can also affect cell organelles as mitochondrial releasing compartment enzymes such as AST. Similarly, our findings show both enzymes AST and ALT was significantly reduced $(\mathrm{P}<0.05)$ in $\mathrm{CE}+\mathrm{EtOH}$ group producing $89.95 \pm 1.18 \mathrm{mmol} / \mathrm{L}$ and $46.75 \pm 0.74 \mathrm{mmol} / \mathrm{L}$, respectively, where, it was comparable with $\mathrm{SD}+\mathrm{EtOH}$ group for both enzymes AST and ALT by $112.19 \pm 6.02$ $\mathrm{mmol} / \mathrm{L}$ and $42.49 \pm 0.62 \mathrm{mmol} / \mathrm{L}$, respectively. Furthermore, consumption of cocoa extract alone showed no significant difference $(\mathrm{P}>0.05)$ compared to control group for both enzymes AST and ALT. The protective properties of cocoa extract may be due to its high phenolic content acting either direct or indirect protection against free radical produced from ethanol metabolism.

$$
\text { SPECIFIC ACTIVITY OF GLUTATHIONE (GSH) }
$$

It has been shown that normal cell activity may generate oxygen radical species called reactive oxygen species (ROS) thus play different positive roles in vivo such as they are used for destruction of microbes and pathogen by white blood cell and being involved in intercellular and intracellular signaling. Major sources of oxygen radicals are through energy production in the mitochondria. Oxygen becomes major concern and interest to researchers because it is highly susceptible to free radical-formation due to its electronic structure. However, excess amounts of oxygenderived radicals are very harmful to the cells and they are also capable to generate other free radical that would be more destructive. Interestingly, our body naturally developed complex antioxidant defense system and its can act at different levels which are radical preventive (first line), radical scavenging (second line), radical induced damage repair (third line) and finally adaptation radical mechanism (fourth line) (Ighodaro \& Akinloye 2018; Niki 1993).

The top first line defense antioxidant, glutathione is an endogenous antioxidant defense that can act to suppress or prevent the formation of free radicals or reactive species in cells. It can neutralize any molecule quite fast with the potential of developing into free radical with the ability to induce the production of other radicals. In turn, increased free radicals exceeding the antioxidant capacity of the cells generating oxidative stress which appears can be highly

TABLE 3. Effect of cocoa extract on liver plasma enzymes of body weights of rats intoxicated with ethanol

\begin{tabular}{lcc}
\hline Groups & AST & ALT \\
\hline Control (distilled water) & $90.66 \pm 2.45 \mathrm{a}$ & $44.46 \pm 1.40 \mathrm{c}$ \\
$300 \mathrm{mg} / \mathrm{kg}$ cocoa extract & $84.31 \pm 1.52 \mathrm{a}$ & $45.87 \pm 0.84 \mathrm{c}$ \\
$4 \mathrm{~g} / \mathrm{kg}$ ethanol & $116.80 \pm 5.23 \mathrm{~b}$ & $56.37 \pm 2.71 \mathrm{~d}$ \\
$300 \mathrm{mg} / \mathrm{kg}$ cocoa extract $+4 \mathrm{~g} / \mathrm{kg}$ ethanol & $89.95 \pm 1.18 \mathrm{a}$ & $46.75 \pm 0.74 \mathrm{c}$ \\
$200 \mathrm{mg} / \mathrm{kg}$ silymarin $+4 \mathrm{~g} / \mathrm{kg}$ ethanol & $112.19 \pm 6.02 \mathrm{~b}$ & $42.49 \pm 0.61 \mathrm{c}$ \\
\hline
\end{tabular}

Data are express as mean \pm SEM $(\mathrm{n}=10)$ for each group for 3 weeks. Mean values followed by same alphabet in the same column are not significantly different at $\mathrm{p}>0.05$

TABLE 4. Effect of cocoa extract on specific activity of glutathione of rats intoxicated with ethanol

\begin{tabular}{ll}
\hline Groups & Glutathione \\
\hline Control (distilled water) & $0.52 \pm 0.04 \mathrm{a}$ \\
$300 \mathrm{mg} / \mathrm{kg}$ cocoa extract & $0.53 \pm 0.02 \mathrm{a}$ \\
$4 \mathrm{~g} / \mathrm{kg}$ ethanol & $0.29 \pm 0.02 \mathrm{~b}$ \\
$300 \mathrm{mg} / \mathrm{kg}$ cocoa extract $+4 \mathrm{~g} / \mathrm{kg}$ ethanol & $0.55 \pm 0.03 \mathrm{a}$ \\
$200 \mathrm{mg} / \mathrm{kg}$ silymarin $+4 \mathrm{~g} / \mathrm{kg}$ ethanol & $0.57 \pm 0.02 \mathrm{a}$ \\
\hline
\end{tabular}

Data are express as mean \pm SEM $(n=10)$ for each group for 3 weeks. Mean values followed by same alphabet in the same column are not significantly different at $\mathrm{p}>0.05$ 
damaging as they can attack biological macromolecules such as lipids, proteins and DNA (Halliwell \& Gutteridge 1999; Valko et al. 2004), which may be enhanced by depletion in antioxidant defense system. Metabolism of ethanol is accompanied by generation of very reactive metabolites i.e. acetaldehyde and free radicals that can readily react oxygen radicals called superoxide anions which can inactivate catalase (Davies 1987; Davies \& Delsignore 1987; Kono \& Fridovich 1982; Mauch et al. 1986) or glutathione. In line with this fact, our findings show that groups of rats which received ethanol showed significantly lower $(\mathrm{P}<0.05)$ glutathione level by $0.29 \pm 0.03$ $\mu \mathrm{mol} / \mathrm{g}$ compared to control groups and groups of rats which received $300 \mathrm{mg} / \mathrm{kg}$ cocoa phenolic extract with or without $4 \mathrm{~g}$ ethanol and $200 \mathrm{mg} / \mathrm{kg}$ silymarin with ethanol by $0.52 \pm 0.05,0.53 \pm 0.02,0.55 \pm 0.03$, and $0.57 \pm 0.02$ $\mu \mathrm{mol} / \mathrm{g}$, respectively (Table 4 ).

Moreover, catalase and other antioxidative enzymes may be inactivated by another ethanol metabolite-1hydroxyethyl radical (Puntarulo et al. 1999). In agreement with high phenolic content and high superoxide anions scavenging of cocoa extract in our previous result (Table 1), strong antioxidant capabilities of flavonoids react either directly or indirectly to scavenge or detoxify free radicals.

\section{Conclusion}

This study has shown that cocoa extract contains significantly high flavonoid content and strong antioxidant activity. In this sense, cocoa extract may prevent oxidation stress induced by ethanol metabolites, which react either directly or indirectly to scavenge free radicals. Moreover, reduction of plasma enzymes (AST and ALT) showed cocoa extract were able to reduce liver injury caused by ethanol consumption. Therefore, our findings suggested that cocoa extract can be a potential antioxidant agent in the prevention of liver disease associated to ethanol consumption.

\section{ACKNOWLEDGEMENTS}

The authors would like to acknowledge the financial assistance provided by the Ministry of Science, Technology and Innovation, Malaysia (IRPA Project No. 05-03-13SF0039). We would also like to thanks Malaysia Cocoa Board and Universiti Kebangsaan Malaysia for the use of facilities and supports.

\section{REFERENCES}

Adam, W.B. 1928. Determination of the color-producing constituents of the cacao bean. The Analyst 53: 369-372.

Ashihara, H., Sano, H. \& Crozier, A. 2008. Caffeine and related purine alkaloids: Biosynthesis, catabolism, function and genetic engineering. Phytochemistry 64(4): 841-856.

Blois, M.S. 1958. Antioxidant determinations by the use of a stable free radical. Nature 181: 1199-1200.

Caballeria, J. 2003. Current concepts in ethanol metabolism. Ann. Hepatol. 2: 60-68.
Cienfuegos-Jovellanos, E., Del Mar, Q., Muguerza, B., Moulay, L., Miguel, M. \& Aleixandre, A. 2009. Antihypertensive effect of a polyphenol-rich cocoa powder industrially processed to preserve the original flavonoids of the cocoa beans. J. Agric. Food Chem. 57: 6156-6162.

Coleman, R.A. 1980. Purine antagonists in the identification of adenosine-receptors in guinea-pig trachea and the role of purines in none-adrenergic inhibitory neurotransmission. Br. J. Pharmacol. 69: 359-366.

Costa, J., Lunet, N., Santos, C., Santos, J. \& Vaz-Carneiro, A. 2010. Caffeine exposure and the risk of Parkinson's disease: A systematic review and meta-analysis of observational studies. J. Alzheimer's Dis. 20: S221-S238.

Davies, K.J. 1987. Protein damage and degradation \& oxygen radicals. I. General aspects. Journal of Biological Chemistry 262: 9895-9901.

Davies, K.J. \& Delsignore, M.E. 1987. Protein damage and degradation by oxygen radicals. III. Modification of secondary and tertiary structure. Journal of Biological Chemistry 262: 9908-9913.

Ellman, G.L. 1959. Tissue sulfhydryl groups. Arch. Biochem. Biophys. 82: 70-77.

Eskelinen, M.H., Ngandu, T., Tuomilehto, J., Soininen, H. \& Kivipelto, M. 2009. Midlife coffee and tea drinking and the risk of late-life dementia: A population-based CAIDE study. Journal of Alzheimer's Disease 16: 85-91.

Fraga, C.G. 2007. Plant polyphenols: How to translate their in vitro antioxidant actions to in vivo conditions. IUBMB Life 59: 308-315.

Franco, R., Oñatibia-Astibia, A. \& Martínez-Pinilla, E. 2013. Health benefits of methylxanthine in cacoa and chocolate. Nutrients 5: 4159-4173.

Haller, S., Rodriguez, C., Moser, D., Toma, S., Hofmeister, J., Sinanaj, I., Van der ville, D., Giannakopoulos, P. \& Lovblad, K.O. 2013. Acute caffeine administration impact on working memory-related brain activation and functional connectivity in the elderly: A BOLD and perfusion MRI study. Neuroscience 250: 364-371.

Halliwell, B. \& Gutteridge, J.M.C. 1999. Chapter 4: Antioxidants from the diet. In Free Radicals in Biology and Medicine. 3rd ed. Oxford: Clarendon Press.

Hammerstone, J.F., Lazarus, S.A., Mitchel, A.E., Rucker, R. \& Schmitz, H.H. 1999. Identification of procyanidins in cocoa (Theobroma Cacao) and chocolate using highperformance liquid chromatography/mass spectrometry. Journal of Agricultural Food Chemistry 47: 490-496.

Han, M.E., Kim, H.J., Lee, Y.S., Kim, D.H., Choi, J.T., Pan, C.S., Yoon, S., Baek, S.Y., Kim, B.S. \& Kim, J.B. 2009. Regulation of cerebral fluid production by caffeine consumption. BMC Neuroscience 10: 110.

Hingson, R. \& Howland, J. 2002. Comprehensive community interventions to promote health: Implication for collegeage drinking problems. J. Stud. Alcohol. 14: 226-240.

Hingson, R., Heeren, T., Winter, M. \& Wechsler, H. 2005. Magnitude of alcohol-related mortality and morbidity among U.S college students ages 18-24: Changes from 1998 to 2001. Annu. Rev. Public Health 26: 259-279.

Hollman, P.C.H., Cassidy, A., Comte, B., Heinonen, M., Richelle, M., Richling, E., Serafini, M., Scalbert, A., Sies, H. \& Vidry, S. 2011. The biological relevance of direct antioxidant effects of polyphenols for cardiovascular health in humans is not established. The Journal of Nutrition 141: 989S-1009S. 
Ighodaro, O.M. \& Akinloye, O.A. 2018. First line defence antioxidant-superoxide dismutase (SOD), catalase (CAT) and glutathione peroxidase (GPX): Their fundamental role in the entire antioxidant defence grid. Alexandria Journal of Medicine 54(4): 287-293.

Kerimi, A. \& Williamson, G. 2015. The cardiovascular benefits of dark chocolate. Vascular Pharmacology 71: 11-15.

Khan, N., Monagas, M., Andres-Lacueva, C., Casas, R., UrpíSardà, M., Lamuela-Raventós, R.M. \& Estruch, R. 2012. Regular consumption of cocoa powder with milk increases HDL cholesterol and reduced oxidized LDL levels in subjects at high-risk of cardiovascular disease. Nutr. Metab. Cardiovasc. Dis. 22: 1046-1053.

Kono, Y. \& Fridovich, I. 1982. Superoxide radical inhibits catalase. Journal of Biological Chemistry 257: 5751-5754.

Koppelstaetter, F., Poeppel, T.D., Siedentopf, C.M., Ischebeck, A., Verius, M., Haala, I., Mottaghy, F.M., Rhomberg, P., Golaszewski, S. \& Gotwald, T. 2008. Does caffeine modulate verbal memory working processes? An fMRI study. NeuroImage 39: 492-499.

Lambert, J.D. \& Elias, R. 2010. The antioxidant and prooxidant activities of green tea polyphenols: A role in cancer prevention. Archieves of Biochemistry and Biophysics 501: 65-72.

Lieber, C.C. 1997. Role of oxidative stress and antioxidant therapy in alcoholic and nonalcoholic liver disease. Advanced Pharmacology 38: 601-628.

Maia, L. \& de Mendonca, A. 2002. Does caffeine intake protect from Alzheimer's disease? Eur. J. Neurol. 9: 377-382.

Martin, M.A., Goya, L. \& Ramos, S. 2016. Antidiabetic actions of cocoa flavonols. Molecular Nutrition and Food Research doi: 10.1002/mnfr.201500961.

Martin, M.A., Goya, L. \& Ramos, S. 2013. Potential for preventive effect of cocoa and cocoa polyphenols in cancer. Food and Chemical Toxicology: An International Journal Published for the British Industrial Biological Research Association 56: 336-351.

Mauch, T.J., Donohue Jr., T.M., Zetterman, R.K., Sorrel, M.F. \& Tuma, D.J. 1986. Covalent binding of acetaldehyde selectively inhibits the catalytic activity of lysinedependent enzymes. Hepatology 6: 263-269.

Nakagawa, H., Hasumi, K., Woo, J., Nagai, K. \& Wachi, M. 2004. Generation of hydrogen peroxide primarily contributes to the induction of $\mathrm{Fe}(\mathrm{II})$-dependent apoptosis in Jurkat cells by (-)-epigallocatechin gallate. Carcinogenesis 25: 15671574

Nehlig, A. 2010. Is caffeine a cognitive enhancer? J. Alzheimer's Dis. 2: S85-S94.

Neufingerl, N., Zebregs, Y.E., Schuring, E.A. \& Trautwein, E.A. 2013. Effect of cocoa and theobromine consumption on serum HDL-cholesterol concentration: A randomized controlled trial. Am. J. Clin. Nutr. 97: 1201-1209.

Nordman, R. 1994. Alcohol and antioxidant system. Alcoholism and Alcohol 29: 513-522.

Orru, M., Bakešová, J., Brugarolas, M., Quiroz, C., Beaumont, V., Goldberg, S.R., Lluís, C., Cortés, A., Franco, R. \& Casadó, V. 2011. Striatal pre- and postsynaptic profile of adenosine A2A receptor antagonists. PLoS ONE 6: e16088.

Othman, A., Amin, I., Nawalyah, A.G. \& Ilham, A. 2007. Antioxidant capacity and phenolic content of cocoa beans. Food Chemistry 100(4): 1523-1530.

Pelligrino, D.A., Xu, H.L. \& Vetri, F. 2010. Caffeine and the control of cerebral hemodynamics. J. Alzheimer's Dis. 20: S51-S62.
Pereira-Caro, G., Borges, G., Nagai, C., Jackson, M.C., Yakota, T., Crozier, A. \& Ashihara, H. 2013. Profiles of phenolic compounds and purine alkaloids during the development of seeds of Theobroma cacao cv. Trinitario. Journal of Agricultural and Food Chemistry 61: 427-434.

Puntarulo, S., Stoyanovsky, D.A. \& Cederbaum, A.I. 1999. Interaction of 1-hydroxyethyl radical with antioxidant enzymes. Archives of Biochemistry and Biophysics 15: 355-359.

Ramos, S. 2008. Cancer chemoprevention and chemotherapy: Dietary polyphenols and signaling pathways. Molecular Nutrition and Food Research 52: 507-526.

Rice-Evans C.A., Miller, N.J. \& Paganga, G. 1997. Antioxidant properties of phenolic compounds. Trends Plant Sci. 2(4): 152-159.

Sallie, R., Tredger, J.M. \& William, R. 1991. Drug and the liver. Biopharm. Drug Dispos. 12: 251-259.

Samman, S., Sandström, B., Toft, M.B., Bukhave, K., Jensen, M. \& Sorensen, S.S. 2001. Green tea or rosemary extract added to foods reduces nonheme-iron absorption. Am. J. Clin. Nutr. 73: 607-612

Shahidi, F. \& Ambigaipalan, P. 2015. Phenolics and polypenolics in foods, beverages and spices: Antioxidant activity and health effects-A review. Journal of Functional Foods 18: 820-897.

Strubelt, O., Younes, M., Urch, T., Breining, H. \& Pentz, R. 1987. Hepatotoxicity of acetaldehyde in rats. Toxicology Letter 39: 77-84.

Sussman, S., Dent, C.W., Skara, S., de Callice, P. \& Tsukamoto, H. 2002. Alcoholic liver disease (ALD): A new domain for prevention effort. Subst. Use Misuse 37: 1887-1904.

Szabo, G. 2003. Pathogenic interactions between alcohol and hepatitis. C. Curr. Gastroenterol. Rep. 5: 86-92.

Usmani, O.S., Belvisim, M.G., Patel, H.J., Crispino, N., Birrell, M.A., Korbonits, D. \& Barnes, P.J. 2005. Theobromine inhibits sensory nerve activation and cough. FAESB J. 19: 231-233.

Valko, M., Izakovic, M., Mazur, M., Rhodes, C.J. \& Telser, J. 2004. Role of oxidation radicals in DNA damage and cancer incidence. Mol. Cell Biochem. 266: 37-56.

Vimala, S., Mohd Ilham, A., Rashih, A.A. \& Rohana, S. 2003. Natural Antioxidants: Piper sarmentosum (Kadok) and Morinda elliptica (Mengkudu). Malaysia Journal of Nutrition 9(1): 41-51.

Wostyn, P., van Dam, D., Audenaert, K. \& de Deyn, P.P. 2011. Increased cerebral fluid production as a possible mechanism underlying Caffeine's protective effect against Alzheimer's disease. Int. J. Alzheimer's Dis. 2011: 617420. doi:10.4061/2011/617420.

Rosmawati Mat Shair \& Rosmin Kasran

Division of Biotechnology

Cocoa Innovation and Technology Centre

Malaysia Cocoa Board, Nilai Industrial Park

71800 Nilai, Negeri Sembilan Darul Khusus

Malaysia

Rosmawati Mat Shair, Mohamad Yusof Maskat* \& Mohamad

Khan Ayob

Center of Biotechnology \& Functional Food

Faculty of Science and Technology

Universiti Kebangsaan Malaysia

43600 UKM Bangi, Selangor Darul Ehsan

Malaysia 
*Corresponding author; email: yusufm@ukm.edu.my

Received: 19 June 2019

Accepted: 15 October 2019 